\title{
PENINGKATAN KAPASITAS LEMBAGA DAN PELAYANAN AIR BERSIH DESA BANTANG DENGAN PENDEKATAN SISTEMIK, HOLISTIK, INTERDISIPLIN DAN PARTISIPATIP (SHIP)
}

\author{
I.N. Sutarja ${ }^{1}$, dan A.A.G.A. Yana ${ }^{2}$
}

\begin{abstract}
ABSTRAK
Beberapa permasalahan yang dihadapi masyarakat Desa Bantang, seperti : 1) masyarakat belum semuanya menikmati air bersih dari Sistem Penyediaan Air Bersih Perdesaan (SPAMDES), 2) belum tertatanya pengolahan sampah rumah tangga dan sampah hasil buangan industri (limbah kulit kopi). Analisis masalah dengan pendekatan SHIP (Sistemik, Holistik, Interdisipliner dan Partisipatip), dan pemecahan masalah dengan beberapa cara antara lain: metode Focus Group Discussion (FGD), penyuluhan, metode pendampingan, metode gotong royong, metode penerapan teknologi tepat guna, dan metode percontohan, melaui KKN-PPM Universitas Udayana. Target yang telah dicapai dalam kegiatan program KKN-PPM ini adalah penerapan teknologi tepat guna, yaitu berupa jaringan SPAMDES mencakup seluruh masyarakat Desa Bantang, Perkuatan kelembagaan SPAMDES Desa Bantang dengan tersusunnya AD/ART dan tarif, serta meningkatnya kesadaran masyarakat untuk mengelola sampah dengan benar dan bermanfaat, serta meningkatnya kesadaran masyarakat untuk menerapkan pola hidup sehat (PHBS).
\end{abstract}

Kata Kunci : peningkatan, kapasitas lembaga, air bersih, pendekatan SHIP, KKN-PPM

\begin{abstract}
Some problems faced by Bantang Village community, such as : 1) not all of them enjoy clean water from the Rural Water Supply System (SPAMDES), 2) not yet known the processing of household waste and industrial waste (waste of coffee skin). Problem analysis with SHIP approach (Systemic approach, Holistic, interdisiplinary and Participatory), and troubleshooting in several ways including: methods of Focus Group Discussion (FGD), counseling, advisory methods, methods of mutual cooperation, methods of applying appropriate technology, and pilot methods, through KKN-PPM Udayana University. The target that has been achieved in this KKN-PPM program activity is the application of appropriate technology, in the form of SPAMDES network covering all Bantang Village community, SPAMDES Desa Bantang Institutional Strengthening with the formulation of AD / ART and tariff, as well as increasing public awareness to manage waste properly and beneficial, as well as increasing public awareness to implement a healthy lifestyle (PHBS)
\end{abstract}

Keywords : improvement, institutional capacity, clean water, SHIP approach, KKN-PPM

\footnotetext{
${ }^{1}$ Staf Pengajar pada Program Studi Teknik Sipil, Fakultas Teknik Universitas Udayana, nsutarja_10@yahoo.com.

${ }^{2}$ Staf Pengajar pada Program Studi Teknik Sipil, Fakultas Teknik Universitas Udayana.
} 


\section{I.N. Sutarja dan A.A.G.A. Yana}

\section{PENDAhULUAN}

Desa Bantang terletak di Kecamatan Kintamani, Kabupaten Bangli, Provinsi Bali. Kondisi geografis Desa Bantang berada pada ketinggian 1400 m diatas permukaan laut dengan suhu 20$30^{\circ} \mathrm{C}$. Desa Bantang terdiri dari dua dusun yaitu Dusun Bantang dan Dusun Panti. Salah satu masalah yang ada di Desa Bantang adalah belum seluruhnya masyarakat menikmati air bersih untuk keluarga yang bersumber dari SPAMDES Desa Bantang. Mereka masih mengambil air dari sumber air terbuka seperti sungai yang tempatnya cukup jauh dari tempat tinggalnya dan kebersihan airnya tidak terjamin.

Melalui KKN - PPM Universitas Udayana diharapkan dapat meningkatkan kapasitas atau layanan air bersih bagi warga yang belum mendapatkannya. Sumber airnya sudah ada, tapi masih terkendala infrastruktur seperti pompa dan pipa untuk mengalirkan air tersebut. Mahasiswa diharapkan dapat mendapingi masyarakat untuk berswadaya membangun infrastruktur tersebut.

Penguatan kapasitas lembaga juga diperlukan seperti : 1) pembuatan Anggaran Dasar dan Anggaran Rumah Tangga (AD/ART) bagi organisasi pengelola SPAMDES, 2) Penetapan tarif yang adil dan terjangkau oleh masyarakat, sehingga akan tersedia cukup dana untuk pemeliharaan infrastruktur air bersih yang sudah dibangun.

Topik ini sangat tepat bagi mahasiwa untuk melaksanakan KKN - PPM di Desa Bantang karena, Kementrian PU-PERA merekomendasikan kepada LPPM Universitas Udayana untuk menjadikan Desa Bantang sebagai sasaran KKN, sehingga mahasiswa dapat mendapingi masyarakat dalam memelihara infrastruktur SPAMDES yang telah dibanguan,

Mengatasi permasalahan masyarakat dan dalam melaksanakan pemecahan permasalahan masyarakat digunakan pendekatan SHIP, yaitu analisis secara Sistemik, Holistik dengan melibatkan semua bidang ilmu (Interdesipliner) dan bersifat Partisipatif dari masyarakat. Pelaksanaannya selalu berdasarkan konsep Teknologi Tepat Guna (TTG) yaitu memenuhi kriteria : Teknis, Ekonomis, Ergonomis, Sosial Budaya, Hemat Energi dan Keberlanjutan. Ada beberapa metode antara lain: metode Focus Group Discussion (FGD), metode penyuluhan, metode pendampingan dan metode gotong royong

\section{HASIL DAN PEMBAHASAN}

\subsection{Peningkatan Penyediaan Air Bersih Bagi Masyarakat}

Peningkatan penyediaan air bersih dengan cara mencari sumber air baru di Dusun Panthi. Program KKM-PPM memberi bantuan mesin pompa dan pipa distribusi, sedangkan mahasiswa bersama masyarakat memasang mesin dan memasang jaringan pipa. Kegiatan ini sudah berhasil menambah debit air yang mengalir sampai ke rumah penduduk seperti Gambat 2.1.

Di Dusun Bantang mahasiswa bersama masyarakat berhasil melakukan kegiatan perbaikan jaringan pipa air yang rusak dan pemeliharaan reservoar yang sempat mengalami kebocoran. Untuk memperkuat organisasi pengelola SPAMDES, telah berhasil disusun dan ditetapkan Angaran Dasar dan Anggaran Rumah Tangga (AD/ART) organisasi dan penetapan tarif dasar air minum. 


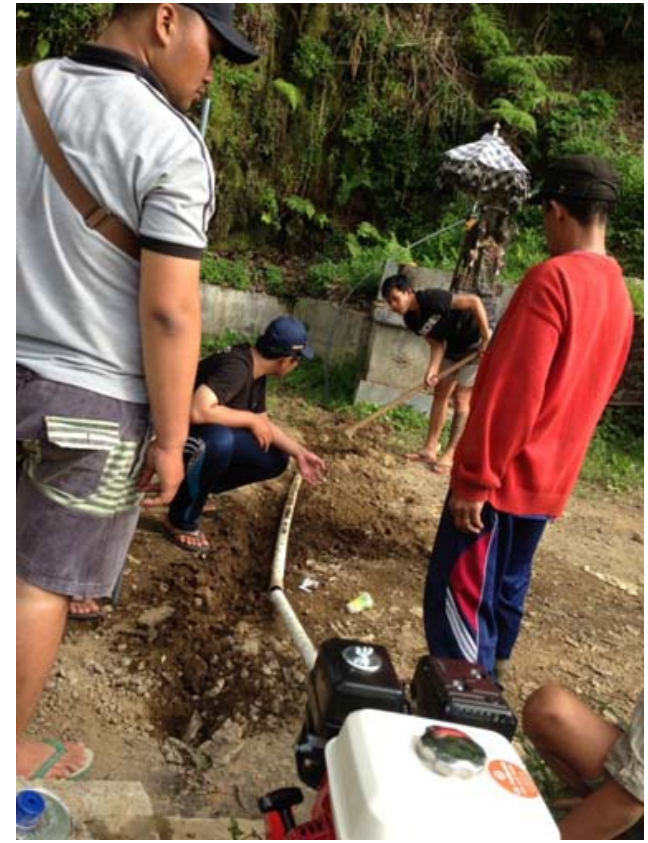

a. Pemasangan Mesin Pompa

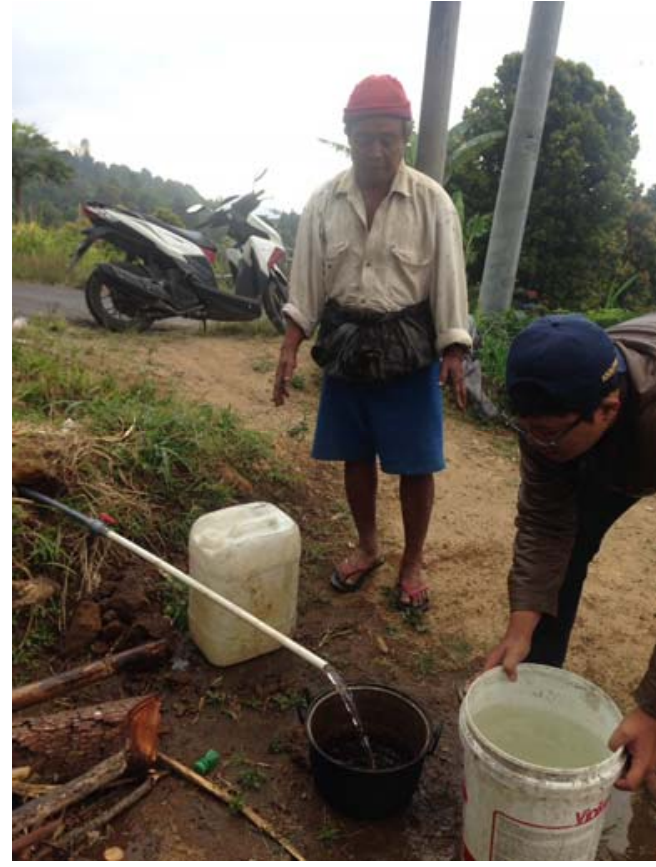

b. Warga Sedang Mengambil Air

Gambar 2.1 Debit Air Bersih Tambahan Sudah Mengalir, dengan Bantuan Mesin Pompa Di Dusun Panti

\subsection{Reboisasi}

Pada tahun 2016, beberapa desa di kecamatan Kintamani, Kabupaten Bangli kena musibah atau bencana tanah longsor yang memakan korban jiwa dan kerugian material yang cukup besar. Tanah longsor di Desa Bantang menimbun sumber air bersih dan merusak lingkungan, dan menyebabkan terputusnya jalan poros dusun. Reboisasi yang telah dilakukan oleh mahasiswa bersama masyarakat dan aparat kecamatan seperti pada Gambar 2.2, merupakan langkah yang tepat untuk mencegah terulangnya bencana tanah longsor.

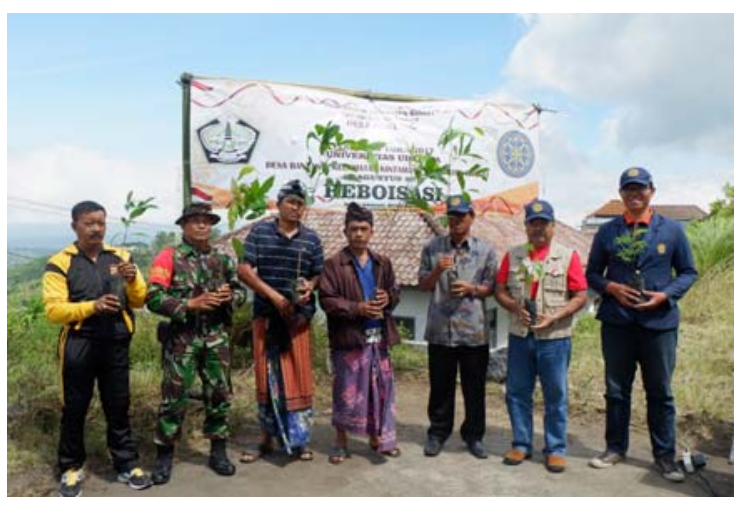

a. Tim Reboisasi Siap Menanam Pohon

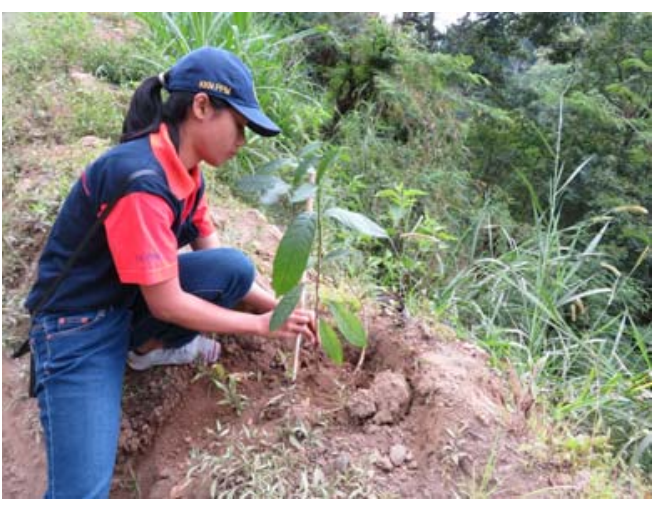

b. Mahasiswi Menanam Pohon

Gambar 2.2 Pelaksanaan Reboisasi oleh Mahasiswa, DPL, Masyarakat, Aparat Desa dan Kecamatan 113 | BULETIN UDAYANA MENGABDI 


\section{I.N. Sutarja dan A.A.G.A. Yana}

\subsection{Pelatihan Pembuatan Makan Ternak dan Pupuk Cair}

Kegiatan Pelatihan Pembuatan Pakan Ternak bertujuan untuk membantu peternak dalam penyediaan pakan substitusi, berguna ketika musim kemarau atau saat hijauan susah untuk didapat sebagai sumber pakan utama ternak. Kegiatan ini juga dibarengi dengan pemeriksaan kesehatan ternak dan memberikan bantuan obat-obatan bagi ternak yang sakit. Untuk peningkatan produktivitas peternak sapi, maka diberikan juga pelatihan pembuatan pupuk cair dengan bahan dasar kotoran sapi.

\subsection{Pelayanan Kesehatan dan Pendampingan Bagi Keluarga Kurang Mampu}

Kegiatan pelayanan kesehatan meliputi pelatihan pola hidup bersih dan sehat bagi anak sekolah dasar, yang dilaksanakan di SDN 1 Desa Bantang. Pendampingan Posyandu dilaksakan bersama petugas kesehatan di Dusun Bantang dan Dusun Panti. Pendampingan bagi keluarga kurang mampu bertujuan untuk mengetahui permasalahan yang mereka hadapi dan membantu memberikan solusi sesuai kemapuan akademis mahasiswa, diantaranya penyuluhan perkebunan jeruk dan pemberian bantuan alat kerja perkebunan yaitu cangkul.

\subsection{Pendekatan SHIP}

Ergonomi adalah ilmu untuk mengaplikasikan pengetahuan tentang karakter, kapasitas dan keterbatasan manusia dalam merancang tuntutan tugas (task), sistem mesin, lingkungan dan ruang gerak sehingga manusia dapat hidup, bekerja dan bermain dengan aman, nyaman dan efisien. Maksud dan tujuan dari penerapan ergonomi dalam perencanaan adalah menciptakan wujud dan suasana ruang yang mampu memberikan rasa aman, sehat dan nyaman berdasarkan pada kaedahkaedah ergonomi. Danang Priatmojo (dalam Hartatik dan Nastiti, 2010), menyebutkan redesain ataupun redevelopment merupakan satu kegiatan dalam garis besar pengembangan kawasan, yang berarti menata kawasan kembali. Penghidupan kembali kawasan dilakukan dengan cara memperbaharui fisik dan non fisik kawasan (proses peremajaan), kemudian ketika proses dilakukan akan ditemukan kebutuhan-kebutuhan baru. Tujuannya adalah untuk menciptakan suatu kawasan dengan kualitas yang lebih baik.

Pendekatan SHIP adalah penerapan kriteria-kriteria Teknologi Tepat Guna (memenuhi kaedah teknis, ekonomis, ergonomis, hemat energi, sosial budaya, ramah lingkungan), yang dianalisis melalui pendekatan yang Sistemik (Systemics), Holistik (Holistics), Interdisipliner (Interdiciplinary) dan Partisipatori (Participatory)/(SHIP Approach) (Manuaba, 2006). Dalam menganalisis suatu permasalahan ergonomi, maka segalanya perlu dipertimbangkan dalam satu kesatuan sistem secara utuh, dikaji dari sudut pandang berbagai disiplin ilmu dan melibatkan berbagai unsur terkait. Di dalam proses penerapannya, pendekatan ergonomi total menekankan adanya pemberdayaan kerja tim, sistem yang demokratis, mengedepankan kolaborasi potensi, membangun keterbukaan, kepercayaan, serta berpandangan jauh ke depan. Salah satu pertimbangan penting yang tidak boleh dilupakan adalah pendekatan kearifan lokal (khususnya konsep Tri Hita Karana), sehingga akan terjadi keselarasan hubungan antara Tuhan - Manusia butha/unsur/alam. 


\section{SIMPULAN DAN SARAN}

Dari kegiatan KKN PPM mahasiswa di Desa Bantang, dapat disimpulkan bahwa :

1. Debit air bersih untuk kebutuhan air minum bagi masyarakat Desa Bantang dapat ditingkatkan melalui pemasangan jaringan baru lengkap dengan mesin pompa dan perbaikan jaringan pipa yang lama.

2. Mahasiswa bersama masyarakat telah melakukan Reboisasi untuk pencegahan tanah longsor dan perlindungan sumber air.

3. Peningkatan produksi petani dilakukan melalui pelatihan pembuatan pakan ternak, pembuatan pupuk cair dan pelayanan kesehatan ternak.

4. Peningkatan kesehatan masyarakat dilakukan oleh mahasiswa melalui pelatihan Pola Hidup Bersih dan Sehat (PHBS) dan pendampingan Posyandu.

5. Mahasiswa melakukan pendampingan bagi keluarga kurang mampu dan memberikan alat bantu kerja berupa cangkul untuk peningkatan produksinya.

Untuk keberhasilan KKN PPM, disarankan salah satu pendekatannya adalah pendekatan (SHIP+TTG) dan pendekatan kearifan lokal (khususnya konsep Tri Hita Karana), sehingga akan terjadi keselarasan hubungan antara Tuhan - Manusia - butha/unsur/alam.

\section{UCAPAN TERIMAKASIH}

Puji dan syukur saya panjatkan kehadapan Ida Syanghyang Widhi Wasa, atas segala rahmatNya sehingga penulisan paper ini dapat diselesaikan. Ucapan terimakasih pula saya sampaikan kepada Kementerian RistekDikti yang telah memberikan bantuan dana untuk pelaksanaan KKN PPM ini.

\section{DAFTAR PUSTAKA}

Direktorat Riset dan Pengabdian Kepada Masyarakat, Direktorat Jenderal Penguatan Riset dan Pengembangan Kementerian Riset, Teknologi, dan Pendidikan Tinggi, 2016, "Panduan Pengusulan Program Penelitian dan Pengabdian Kepada Masyarakat Melalui SIMLITABMAS", Jakarta

Direktorat penelitian dan pengabdian kepada masyarakat direktorat jenderal pendidikan tinggi kementerian pendidikan dan kebudayaan, 2013, "Panduan pelaksanaan penelitian dan pengabdian kepada masyarakat di perguruan tinggi", edisi IX, Ja

Direktorat penelitian dan pengabdian kepada masyarakat direktorat jenderal pendidikan tinggi kementerian pendidikan dan kebudayaan, 2013, "Panduan pelaksanaan hibah kuliah kerja nyata pembelajaran pemberdayaan masyarakat (KKN-PPM)", Jakarta.

Fakultas Teknik UNUD, 2013, Buku pedoman akademik Fakultas Teknik Universitas Udayana, Bali.

Hartatik, P.S. dan Sri Nastiti N.N., 2010, Peningkatan Kualitas Hidup Penghuni di Rusunawa Urip Sumoharjo Pasca Redevelopment, Surabaya, disampaikan dalam Seminar Nasional Perumahan Permukiman Dalam Pembangunan Kota,

Manuaba. A., 2006, Aplikasi Ergonomi dengan Pendekatan Holistik perlu, demi hasil yang lebih Lestari dan mampu bersaing, Jurnal Sosial dan Humaniora, Volume 01 Nomor 03:235-249.

Nala, I.G.N., 1987, Penerapan Teknologi Tepat Guna di Pedesaan, Denpasar, Lembaga pengabdian Kepada masyarakat, Universitas Udayana.

Lembaga Penelitian dan Pengabdian Kepada Masyarakat, Universitas Udayana, 2016, "Buku Pedoman Kuliah Kerja Nyata - Pembelajaran Pemberdayaan Masyarakat (KKN PPM).

Sutarja, I.N., 2014, Pembangunan Infrastruktur Perdesaan Berbasis Ergonomi Total Yang Inklusif Dan Berkelanjutan, Udayana University Press, Denpasar.

\section{5 | BULETIN UDAYANA MENGABDI}

